\title{
Analisis Optimasi Perencanaan Ulang Access Point WiFi Dengan Model Pathloss COST 231 Multi Wall dan Metode Offered Bit Quantity (OBQ) Studi Kasus Gedung Telematika ITTP
}

\section{The Optimization Analysis of WiFi Access Point Replanning by Multi-Wall 231 COST Pathloss Model and Offered But Quantity (OBQ) for The Case Study of ITTP Telematika Building}

\author{
Muntaqo Alfin Amanaf ${ }^{1, *}$, Eka Setia Nugraha ${ }^{2}$, Lina Azhari ${ }^{3}$ \\ 1,2 Program Studi D3 Teknik Telekomunikasi, ${ }^{3}$ Program Studi S1 Teknik Telekomunikasi, \\ Fakultas Teknik Telekomunikasi dan Elektro, Institut Teknologi Telkom Purwokerto \\ JL. DI Panjaitan No.128 Purwokerto, 53147, Jawa Tengah, Indonesia \\ 1,*Penulis korespondensi: muntaqo@ittelkom-pwt.ac.id
}

Received on 17-12-2019, accepted on 21-01-2019, published on 28-01-2019

Abstract

IT Telkom Purwokerto (ITTP) merupakan salah satu perguruan tinggi yang memanfaatkan jaringan WiFi untuk civitas akademiknya. Namun pada beberapa area masih terdapat pengguna yang mendapatkan kuat sinyal dengan kategori buruk. Dari jumlah access point (AP) existing sebanyak 15 AP masih terdapat area yang belum ter-cover jaringan WiFi dengan baik. Hal tersebut dibuktikan dengan hasil simulasi AP existing yang menunjukan nilai Receive Signal Level (RSL) pada lantai 2 dan lantai 3 sebesar $-74 \mathrm{dBm}$ dan $-79 \mathrm{dBm}$ dimana nilai RSL tersebut dikategorikan buruk sehingga perlu dilakukan optimasi penempatan access point pada gedung penelitian. Penelitian ini melakukan perhitungan coverage (cakupan wilayah) dengan metode COST 231 Multi wall model dan capacity (kapasitas pengguna) dengan metode OBQ untuk mendapatkan jumlah AP. Berdasarkan perhitungan, didapatkan jumlah AP sebanyak 26 AP dari perhitungan coverage dan 20 AP dari perhitungan capacity. Dari jumlah AP yang didapatkan kemudian disimulasikan menggunakan simulator RPSv5.4 dengan frekuensi $2,4 \mathrm{GHz}$ dan model propagasi COST 231 Multiwall. Untuk mengetahui jumlah AP dan penempatan AP yang optimal maka dilakukan perbandingan 4 skenario penempatan dengan melihat hasil parameter RSL dan Signal Interference Ratio (SIR). Hasil yang didapat berdasarkan perhitungan, terdapat penambahan jumlah AP dari 15 AP menjadi 26 AP serta pergeseran letak AP agar seluruh area ter-cover dengan baik. Dari hasil RSL dan SIR pada simulasi optimasi, jumlah AP yang optimal yaitu 26 AP dengan posisi AP ditempatkan ditepi bagian depan dengan hasil RSL pada keseluruhan lantai sebesar $-27,27 \mathrm{dBm}$ dan SIR sebesar 4,05 dB.

Keywords: COST 231 Multi wall, OBQ, RSL, SIR 


\begin{abstract}
IT Telkom Purwokerto (ITTP) is one of the universities that utilize the WiFi network for its academic community. However, there are still users who get a strong signal with a wrong category in some areas. There are still areas that the WiFi network has not adequately covered from the number of existing access points (APs) as many as 15 APs, there are still areas that the WiFi network has not adequately covered. The existing AP simulation shows the Receive Signal Level (RSL) value on the 2 nd and 3rd floors of $-74 \mathrm{dBm}$ and $\mathbf{- 7 9} \mathrm{dBm}$, where the RSL value is categorized as bad, so it is necessary to optimize the placement of access points in the research building. This study calculates coverage (area coverage) with the COST 231 Multiwall model method and capacity (user capacity) with the OBQ method to get the number of APs. Based on the calculations, the number of APs obtained is 26 APs from the coverage calculation and 20 APs from the capacity calculations. The number of APs obtained was then simulated using the RPSv5.4 simulator with a frequency of $2.4 \mathrm{GHz}$ and the COST 231 Multiwall propagation model. To find out the optimal number of APs and the placement of APs, a comparison of 4 placement scenarios was carried out by looking at the results of the RSL and Signal Interference Ratio (SIR) parameters. The results obtained are based on calculations. There is an increase in the number of APs from 15 APs to 26 APs and a shift in the location of APs so that the entire area is adequately covered. From the results of RSL and SIR in the optimization simulation, the optimal number of APs is 26 APs with the AP position placed on the edge of the front with the results of RSL on the entire floor of $27.27 \mathrm{dBm}$ and SIR of $4.05 \mathrm{~dB}$.
\end{abstract}

Keywords: COST 231 Multi wall, OBQ, RSL, SIR

\title{
I. Pendahuluan
}

Internet merupakan layanan komunikasi yang memberikan kemudahan dalam proses pengiriman data secara online dan realtime. Untuk mengakses internet dapat dilakukan dengan berbagai cara diantaranya yaitu dengan menggunakan jaringan Local Area Network (LAN) maupun menggunakan jaringan komunikasi data seperti wireless dan sebagainya. Kebutuhan akan koneksi komunikasi wireless atau biasa disebut Wireless Fidelity (Wi-Fi) saat ini sangat diminati oleh pengguna layanan internet. Wi-Fi merupakan salah satu bentuk teknologi alternatif yang lebih murah untuk diimplementasikan pada lokasi area publik atau lingkungan kerja seperti kampus, perpustakaan, bandara, cafe dan sebagainya.

Kinerja suatu jaringan $\mathrm{WiFi}$, misalnya pada suatu gedung atau ruangan dapat diketahui dari kuat sinyal yang diterima dari transmitter (Tx) ke receiver $(\mathrm{Rx})$. Selain itu, dapat juga ditinjau dari aspek-aspek propagasi gelombang radio dalam ruangan (indoor propagation) seperti jenis material gedung, tembok, meja dan objek lain yang dikategorikan sebagai penghalang yang dapat melemahkan gelombang radio. Penghalang tersebut akan memberikan pengaruh yang berbeda bagi pancaran radio dari perangkat access point (AP). Selain itu, aspek propagasi gelombang radio dalam ruangan juga akan berpengaruh pada luas total area cakupan $\mathrm{WiFi}$, peletakan AP dan jumlah AP yang digunakan.

Pada penelitian [1] telah dibahas mengenai analisis penerapan model propagasi empiris COST $231 \mathrm{Multi}$ Wall pada gedung Swalayan dengan mempertimbangkan jenis material dinding/penghalang dalam bangunan indoor berupa jarak antar rak dibuat beragam. Hasil yang didapatkan yaitu semakin banyak sekat maka semakin kecil jari-jari sel sehingga semakin besar jumlah access point yang dibutuhkan begitu pula sebaliknya. Selanjutnya, pada penelitian [2] dibahas mengenai perencanaan indoor WiFi IEEE 802.11n pada Gedung Tokong Nanas dengan melakukan perhitungan capacity planning dan coverage planning untuk mendapatkan jumlah access point. Sedangkan pada penelitian [3] dilakukan simulasi pemodelan COST 231 Multi Wall di gedung Gedung Telematika ITTP tetapi bukan untuk perencanaan ulang WIFI melainkan untuk aplikasi Wireless Sensor Network dalam perencanaan absensir berbasi RF-ID.

Pada penelitian ini, dilakukan perencanaan ulang access point menggunakan software Radiowave Propagation Simulator. Perhitungan jumlah AP untuk optimasi permcanaan ulang berdasarkan perhitungan coverage (cakupan wilayah) dengan metode COST 231 Multiwall dan capacity (kapasitas pengguna) dengan metode OBQ kemudian disimulasikan menggunakan software RPS. Hasil simulasi dianalisa dengan melihat parameter Receive Signal Level (RSL) dan Signal to Interference Ratio (SIR). 


\section{Metode Penelitian}

Metode yang digunakan dalam penelitian ini diantaranya yaitu penulis mensimulasikan penempatan access point (AP) existing, melakukan perhitungan jumlah AP, dan melakukan optimasi perencanaan ulang penempatan AP sesuai jumlah AP perhitungan. Simulasi yang dilakukan menggunakan software Radiowave Propagation Simulator (RPS) v5.4 dengan frekuensi 2,4 GHz dan model propagasi COST 231 Multiwall. Lokasi gedung sebagai studi kasus penelitian yaitu di gedung Telematika ITTP. Sebelum melakukan optimasi, penempatan AP existing dengan jumlah 15 AP disimulasikan untuk melihat parameter Receive Signal Level (RSL), dan Signal to Interference Ratio (SIR). Optimasi penempatan AP dilakukan berdasarkan perhitungan link budget dan perhitungan kapasitas pengguna. Setelah didapatkan jumlah AP dari perhitungan, akan dilakukan simulasi berdasarkan 4 skenario dimana skenario 1 AP diposisikan ditengah ruangan, skenario 2 AP diposisikan ditepi bagian belakang, skenario 3 AP diposisikan ditepi bagian depan, dan skenario 4 AP diposisikan Zig-Zag. Dari jumlah AP perhitungan cakupan wilayah dan kapasitas pengguna, masing-masing akan dilakukan simulasi sesuai 4 skenario tersebut untuk menghasilkan parameter RSL dan SIR pada keseluruhan lantai, lantai 1, lantai 2 dan lantai 3 yang kemudian dari hasil tersebut akan diambil nilai RSL dan SIR terbaik untuk dibandingkan dengan hasil simulasi penempatan AP existing. Adapun flowchart metode penelitian ditunjukan pada gambar 2.

\section{Teknologi Wireless Fidelity (WiFi)}

Wireless Fidelity atau sering disebut dengan istilah WiFi merupakan kumpulan standar yang digunakan untuk jaringan Lokal Nirkabel (Wireless Local Area Network-WLAN) yang distandarisasi oleh IEEE. Istilah WiFi dicetuskan oleh sebuah firma konsultasi merk yaitu Interbrand Corporation, dan pertama digunakan secara komersial pada tahun 1999. [4] WiFi dirancang berdasarkan standar dari IEEE 802.11 dengan standar yang dikeluarkan yaitu $802.11 \mathrm{a} / \mathrm{b} / \mathrm{g} / \mathrm{n} / \mathrm{ac}$. [5]

\section{Channel Frekuensi 2,4 GHz}

Pada komunikasi wireless, penggunaan secara bersamaan pada channel 1 dan channel 2 akan mengakibatkan terjadinya interferensi. Gambar 2 merupakan penggunaan channel WiFi.

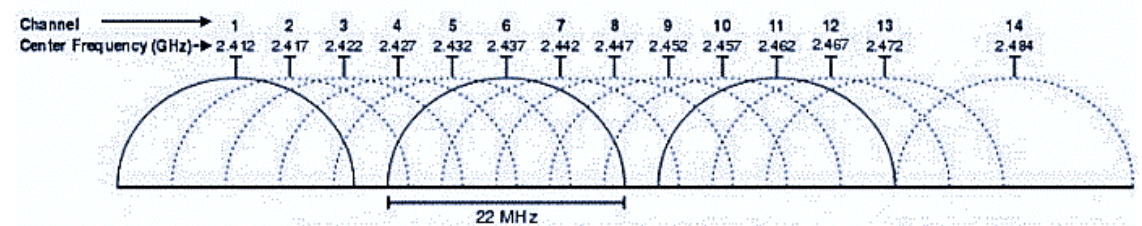

Gambar 1. Representasi Channel WiFi 2,4 GHz [6] 


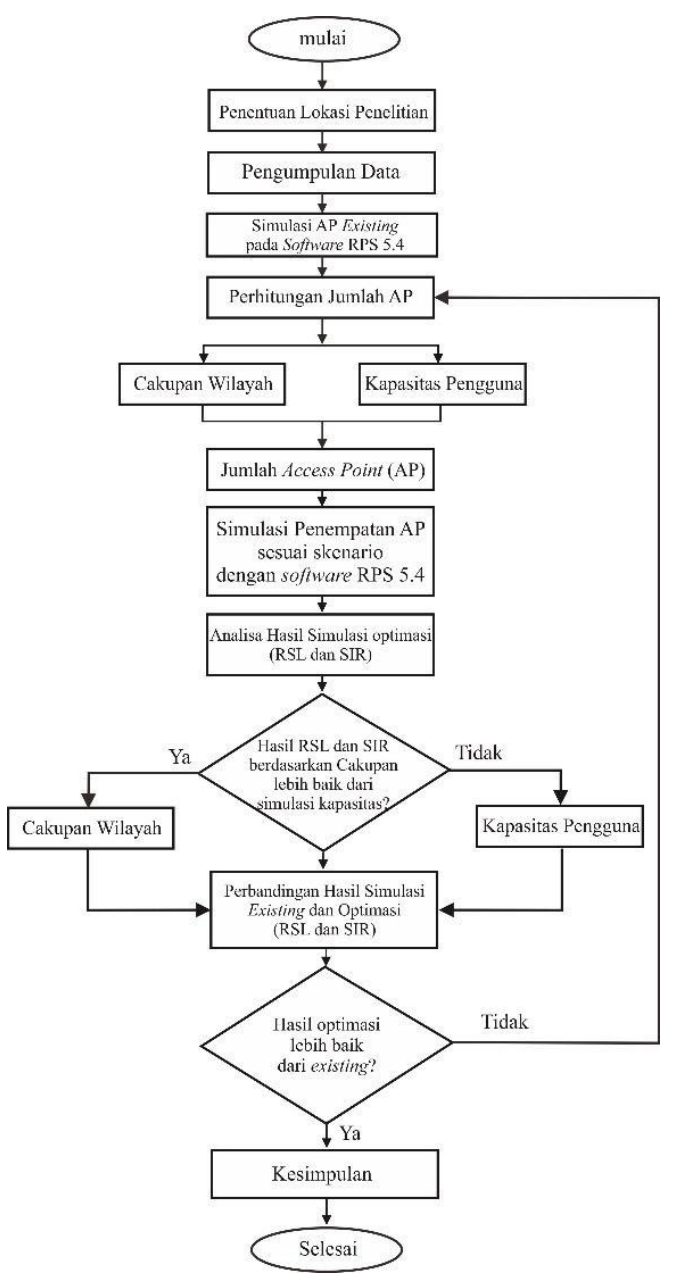

Gambar 2. Flow chart Metode Penelitian

Received Signal Level (RSL)

RSL merupakan indeks yang menunjukkan kuat sinyal yang diterima dari transmitter (Tx) ke receiver (Rx). Tabel 1 menunjukan standar kuat sinyal WiFi yang diklasifikasikan sebagai berikut.

Tabel 1. Standar RSL WiFi [7]

\begin{tabular}{|c|c|}
\hline Kualitas & Kuat sinyal $(\mathbf{d B m})$ \\
\hline Exceptional & Better than -40 \\
\hline Very Good & -40 to -55 \\
\hline Good & -55 to -70 \\
\hline Marginal & -70 to -80 \\
\hline $\begin{array}{c}\text { Intermittent to No } \\
\text { Operation }\end{array}$ & -80 and beyond \\
\hline
\end{tabular}

Informasi Gedung

Lokasi gedung penelitian yaitu di gedung Telematika ITTP dimana gedung tersebut memanfaatkan jaringan WiFi untuk civitas akademiknya sehingga membutuhkan akses data/internet yang cepat dan lancar setiap harinya. Optimasi dilakukan pada gedung lantai 1, lantai 2, lantai 3, dan Kafetaria dengan luas total $2.813,5 \mathrm{~m}^{2}$. Tabel 2 merupakan rincian luas gedung penelitian 
Tabel 2. Rincian luas gedung

\begin{tabular}{|c|c|}
\hline Lantai & Luas $\left(\mathbf{m}^{\mathbf{2}}\right)$ \\
\hline 1 & 1.494 \\
\hline 2 & 863,5 \\
\hline 3 & 456 \\
\hline Luas Total & $2.813,5$ \\
\hline
\end{tabular}

Perhitungan Jumlah AP berdasarkan Cakupan Wilayah dengan model propagasi COST 231 Multiwall

Terdapat beberapa tahapan untuk menghitung jumlah AP berdasarkan cakupan wilayah yaitu

\section{Link Budget}

Link budget adalah metode untuk mempertimbangkan jangkauan cakupan untuk suatu sel. Dibutuhkan Maximum Allowed Path Loss (MAPL) agar diperoleh jari-jari radius sel access point. Perhitungan link budget digunakan untuk memperkirakan nilai MAPL atau maksimal pelemahan sinyal yang diterima antara transmitter dan receiver. Untuk menghitung MAPL dengan persamaan berikut [8]

$$
\mathrm{MAPL}=\mathrm{Pt}+\mathrm{Gt}-\mathrm{Lt}+\mathrm{Gr}-\mathrm{Lr}-\mathrm{Pr}
$$

Keterangan: Pt: Daya pancar $(\mathrm{dB})$, Gt: Penguatan antena pemancar (dBi), Lt: Rugi-rugi pada pemancar/Cable loss AP, Gr: Penguatan pada antena penerima (dB), Lr: Rugi-rugi karena saluran penerima/Cable loss client $(\mathrm{dB})$, Pr: Expected received signal level $(\mathrm{dBm})$.

\section{Redaman Indoor}

Redaman indoor bertujuan untuk menghasilkan nilai dari Loss wall material yang berarti bahwa setiap penghalang memiliki daya redam terhadap sinyal. Tabel 3 menunjukan nilai redaman material.

Tabel 3 Nilai Redaman [9]

\begin{tabular}{|c|c|}
\hline Material & Redaman (dB) \\
\hline Glass & 0,8 \\
\hline Wood & 2,8 \\
\hline Brick & 3,5 \\
\hline Metal & 6 \\
\hline $\begin{array}{c}\text { Metal door in brick } \\
\text { wall }\end{array}$ & 12,4 \\
\hline Plasterboard Wall & 4 \\
\hline Window & 2 \\
\hline Wood Door & 4 \\
\hline Cinder Block & 7 \\
\hline Dry Wall & 4 \\
\hline
\end{tabular}

\section{Loss Total}

Untuk menghitung loss total dilakukan dengan cara menjumlahkan nilai MAPL dengan Soft Handover Gain lalu dikurangkan dengan nilai total loss penghalang.

\section{Model Propagasi Indoor COST 231 Multiwall}

Pada penelitian ini menggunakan model propagasi COST 231 Multiwall. Penggunaan model propagasi ini bertujuan untuk memprediksi daya sinyal rata-rata. [9]

$$
\mathrm{LT}=L_{F S L}+L c+\sum_{i=1}^{M} \quad n w i x L w i+n f^{\left[\frac{n f+2}{n f+1}-b\right]} \cdot L f
$$


Keterangan: LT: Maximum Allowed Path Loss (MAPL), LFsL: Free Space Loss transmitter dan receiver, $\mathrm{L}_{\mathrm{c}}$ : Konstanta Loss $(37 \mathrm{~dB})$, nwi: Jumlah dinding yang dilewati, Lwi: Penetrasi loss dari tipe wall, M: Number of Wall type, Lf: Loss per lantai, nf: Jumlah lantai yang dilewati, b: Konstanta empiris.

$\mathrm{FSL}=20 \log \mathrm{f}(\mathrm{MHz})+20 \log \mathrm{d}(\mathrm{km})+32,5$

Keterangan : FSL: Free Space Loss, f: frekuensi (MHz), d: jarak antara transmitter (Tx) dan receiver (Rx) dalam satuan $\mathrm{km}$.

\section{Forecast $A P$}

Perhitungan forecast AP digunakan untuk menghitung berapa AP yang dibutuhkan untuk dapat mengcover seluruh gedung.

Cell Width $=2,6 \times \mathrm{d}^{2}$

Keterangan: Cell width: luas area sel, d: jarak pengirim dan penerima (m).

$$
\text { Jumlah FAP }=\frac{\text { Luas Area yang perancangan }}{\text { Cell Width }}
$$

Keterangan: Jumlah FAP: Jumlah access point (AP), cell width: luas area sel.

Pehitungan Jumlah AP berdasarkan Kapasitas Pengguna

1. Service Model

Service model merupakan informasi mengenai jenis layanan yang digunakan oleh pengguna. Informasi dari service model digunakan sebagai acuan dalam melakukan perhitungan Offered But Quantity (OBQ).

2. Offered Bit Quantity (OBQ)

Perhitungan OBQ bertujuan untuk mengetahui total bit yang diperlukan oleh pengguna WiFi berdasarkan service model. [9]

$$
\mathrm{OBQ}=\mathrm{Ct} \times \mathrm{C}(\mathrm{u} ; \mathrm{t}) \times \mathrm{P} \times \mathrm{Rb}(\text { service }) \times \mathrm{B} \times \mathrm{h}
$$

Keterangan: Ct: Tipe presentase user (pada kasus ini adalah 100\% user digedung), C(u;t): Jumlah pengguna WiFi, P: Penetrasi service user, $\mathrm{Rb}$ (service): Bearer rate dari layanan, $\mathrm{B}$ : Busy Hour Service Attempts (BHSA), H: Durasi menggunakan layanan.

\section{Forecast AP}

Forecast AP bertujuan untuk menghitung berapa access point ideal agar seluruh pengguna WiFi dapat ter-cover. [9]

$$
\begin{aligned}
& \text { Peak Data Rate }=\frac{\text { Number } \text { of } \text { Data } \text { Carrier }}{I D F T \text { Period }+ \text { GI }} \times \log _{2}(\text { modulation }) \times \text { code rate } \times \text { MIMO } \\
& \text { Number of } \mathrm{AP}=\frac{\text { OBQ total }(\mathrm{Mbps})}{\text { Peak Data Rate of } A P(\mathrm{Mbps})}
\end{aligned}
$$

\section{Skenario Penempatan AP optimasi}

Terdapat 4 skenario yang akan disimulasikan setelah mendapatkan jumlah AP berdasarkan cakupan wilayah dan kapasitas pengguna. Skenario tersebut diantaranya yaitu skenario 1 AP diposisikan ditengah (gambar 3), skenario 2 AP diposisikan ditepi bagian belakang (gambar 4), skenario 3 AP diposisikan ditepi bagian depan (gambar 5), dan skenario 4 AP diposisikan Zig Zag (gambar 6). 
MUNTAQO ALFIN AMANAF, DKK:

JTECE. VOL. 01, NO. 01, PP.35-48, JAN 2019

1. Skenario 1 (AP diposisikan ditengah)

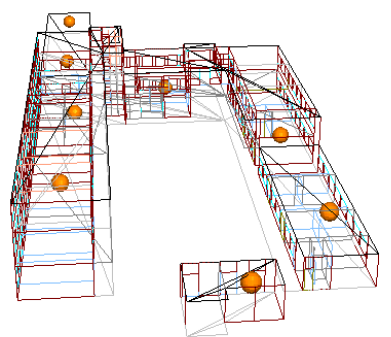

Gambar 3. Penempatan AP skenario 1

2. Skenario 2 (AP diposisikan ditepi bagian belakang)

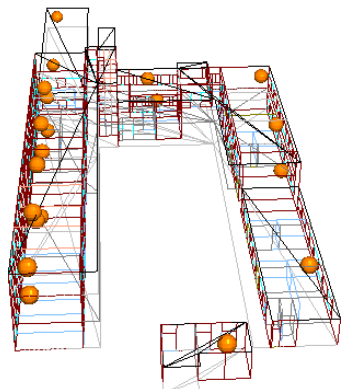

Gambar 4. Penempatan AP skenario 2

3. Skenario 3 (AP diposisikan ditepi bagian depan)

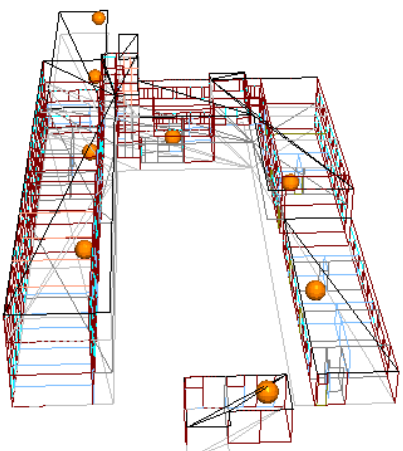

Gambar 5. Penempatan AP skenario 3 
4. Skenario 4 (AP diposisikan Zig-Zag)

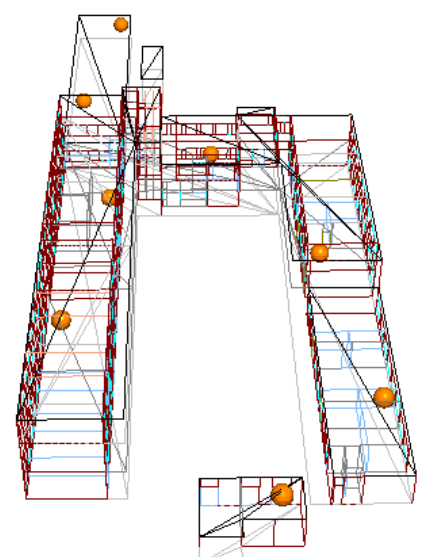

Gambar 6. Penempatan AP skenario 4

\section{METODE PENELITIAN}

\section{A. Hasil Simulasi AP Existing}

Gambar 7 menunjukan hasil RSL AP existing dari simulasi RPS yang ditunjukan dengan penyebaran warna pada area perancangan. Terdapat berbagai macam warna yang ditampilkan yang menandakan RSL yang diterima pengguna memiliki nilai yang bervariasi dengan nilai maksimal RSL sebesar $-17 \mathrm{dBm}$ dan minimum RSL - $64 \mathrm{dBm}$ pada penempatan keseluruhan lantai.

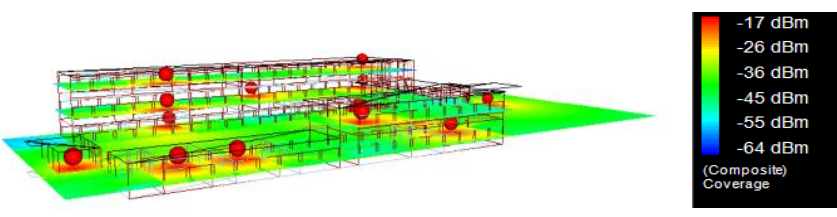

Gambar 7. 3D Coverage Plot AP Existing

Adapun hasil RSL AP existing yang ditunjukan dengan chart diagram dapat dilihat pada gambar 8 .

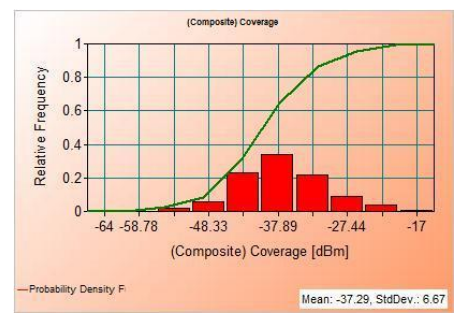

Gambar 8. Chart Diagram RSL AP existing

Sumbu horizontal menunjukan kuat sinyal yang diterima oleh pengguna, sedangkan sumbu vertikal menunjukan nilai relative frekuensi yaitu nilai presentase dari probabilitas pengguna untuk mendapatkan level daya. Rata-rata RSL yang diterima sebesar - $37,29 \mathrm{dBm}$ dan minimum RSL yang diterima yaitu sebesar $-64 \mathrm{dBm}$. Nilai relative frekuensi didapatkan sebesar 0,38 yang berarti sebanyak $38 \%$ dari $100 \%$ pengguna mendapatkan RSL sebesar -37,89 dBm. 
Dapat dilihat pada gambar 9 dan gambar 10 menunjukan hasil SIR pada penempatan AP existing. Pada gambar 9 SIR ditampilkan dengan berbagai macam warna pada area perancangan yang menandakan pada area perancangan memiliki SIR yang bervariasi. Pada informasi legend, nilai maksimum SIR sebesar 35 $\mathrm{dB}$ yang di representasikan dengan warna merah dan minimum SIR sebesar $-7 \mathrm{~dB}$ yang di representasikan dengan warna biru.

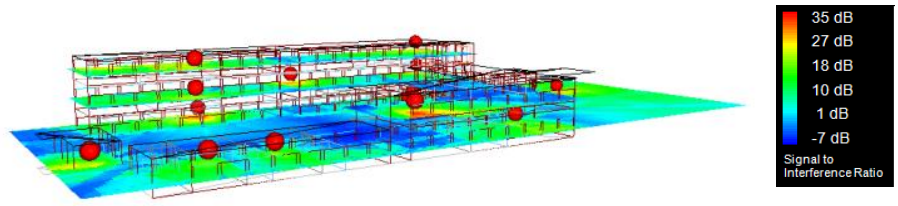

Gambar 9. 3D SIR Plot AP existing

Kemudian pada gambar 10 menunjukan chart diagram hasil simulasi SIR. Didapat kualitas dengan nilai 2,33 dB (SIR kategori normal) sebagai nilai yang paling banyak didapat oleh area perancangan yaitu dengan presentase 21\%. Sedangkan kualitas SIR terendah yaitu -7 dB (SIR kategori buruk).

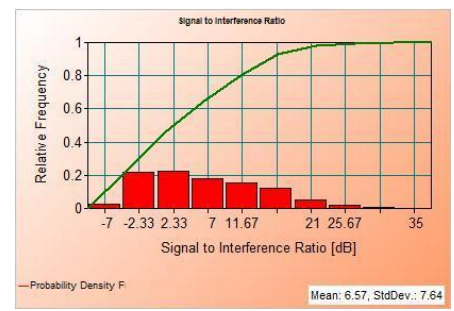

Gambar 10. Chart Diagram SIR Penempatan AP Existing

Hasil RSL keseluruhan lantai, lantai 1, lantai 2, dan lantai 3 pada penempatan AP existing ditunjukan pada gambar 11. Berdasarkan diagram chart, rata-rata RSL dikategorikan bagus (pada rentang $-40 \mathrm{dBm}$ hingga $-55 \mathrm{dBm}$ ). Akan tetapi minimum RSL pada lantai 2 sebesar $-74 \mathrm{dBm}$, dan lantai 3 sebesar $-79 \mathrm{dBm}$ yang berarti masih terdapat pengguna yang mendapatkan RSL dalam kategori buruk. Dari hasil minimum RSL pada lantai 2 dan 3 maka perlu dilakukan optimasi penempatan AP pada gedung penelitian.

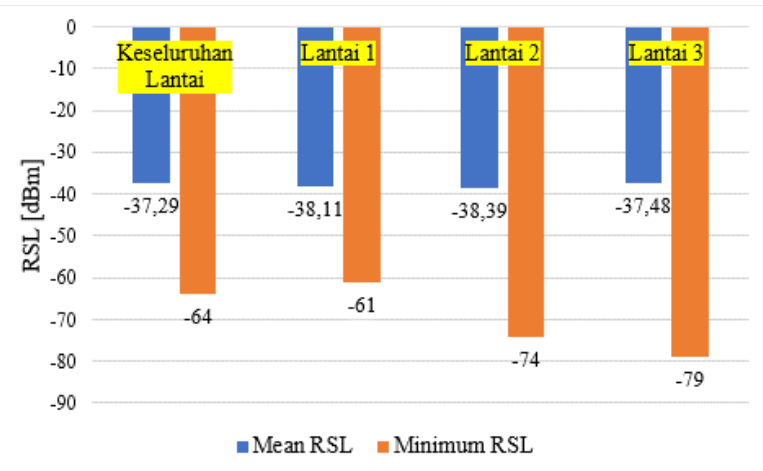

Gambar 11. Diagram Chart RSL simulasi Existing

\section{B. Perhitungan Jumlah AP}

Jumlah AP berdasarkan perhitungan cakupan wilayah yaitu sebanyak 26 AP sedangkan berdasarkan perhitungan kapasitas pengguna sebanyak 20 AP. Tabel 4 menunjukan penempatan AP pada masingmasing lantai. 
Tabel 4. Penempatan Access Point per lantai

\begin{tabular}{|c|c|}
\hline \multicolumn{2}{|c|}{$\begin{array}{l}26 \text { AP berdasarkan cakupan } \\
\text { wilayah }\end{array}$} \\
\hline Lantai 1 & $15 \mathrm{AP}$ \\
\hline Lantai 2 & $8 \mathrm{AP}$ \\
\hline Lantai 3 & $3 \mathrm{AP}$ \\
\hline \multicolumn{2}{|c|}{$\begin{array}{c}20 \mathrm{AP} \text { berdasarkan kapasitas } \\
\text { pengguna }\end{array}$} \\
\hline Lantai 1 & $8 \mathrm{AP}$ \\
\hline Lantai 2 & $7 \mathrm{AP}$ \\
\hline Lantai 3 & $5 \mathrm{AP}$ \\
\hline
\end{tabular}

\section{Hasil Simulasi Optimasi}

1. Perbandingan RSL dan SIR 26 AP dan 20 AP

Setelah melakukan simulasi optimasi menggunakan 4 skenario pada masing-masing jumlah AP sebanyak 26 AP dan 20 AP, selanjutnya yaitu membandingkan hasil RSL dan SIR pada keseluruhan skenario untuk melihat manakah dari 4 skenario tersebut yang menghasilkan RSL dan SIR terbaik. Tabel 5 merupakan perbandingan hasil RSL dan SIR dari jumlah 26 AP dan 20 AP.

Tabel 5. Perbandingan Keseluruhan Skenario

\begin{tabular}{|c|c|c|c|}
\hline $\begin{array}{c}\text { Jumlah } \\
\text { AP }\end{array}$ & Skenario & $\begin{array}{c}\text { RSL } \\
(\mathrm{dBm})\end{array}$ & $\begin{array}{c}\text { SIR } \\
(\mathrm{dB})\end{array}$ \\
\hline \multirow{4}{*}{26 AP } & 1 & $-27,54$ & 4,25 \\
\cline { 2 - 4 } & 2 & $-28,49$ & 3,68 \\
\cline { 2 - 4 } & 3 & $-27,27$ & 4,05 \\
\cline { 2 - 4 } & 4 & -27.60 & 4,06 \\
\hline \multicolumn{3}{|c|}{} \\
\hline \multirow{3}{*}{$20 \mathrm{AP}$} & 1 & $-29,21$ & 5,01 \\
\cline { 2 - 4 } & 2 & $-30,20$ & 4,57 \\
\cline { 2 - 4 } & 3 & $-28,89$ & 5,03 \\
\cline { 2 - 4 } & 4 & $-29,22$ & 5,01 \\
\hline
\end{tabular}

Terlihat pada tabel 5 bahwa posisi access point (AP) yang memiliki nilai RSL paling tinggi adalah skenario 3 dengan jumlah 26 AP. Nilai SIR yang dihasilkan pada keseluruhan skenario dari penempatan 26 AP dan 20 AP masih dalam kategori normal. Berdasarkan hasil tersebut penulis memilih skenario 3 (posisi AP berada ditepi bagian depan) dengan jumlah AP sebanyak 26 AP karena skenario 3 menghasilkan nilai RSL yang lebih tinggi dari hasil RSL pada skenario yang lain.

2. Skenario $326 \mathrm{AP}$

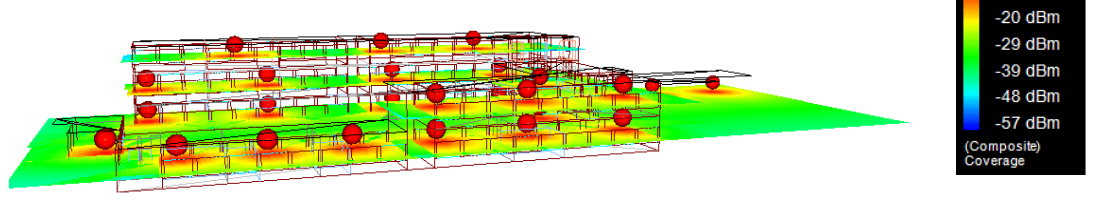

Gambar 12. Diagram Chart RSL simulasi Existing

Gambar 12 merupakan hasil RSL skenario 3 dengan posisi AP ditempatkan ditepi bagian depan yang ditunjukan dengan penyebaran warna pada area perancangan. Semakin dekat dengan AP maka RSL yang diterima oleh pengguna semakin tinggi yang ditandai dengan legend warna merah. Dari hasil penyebaran warna yang ditampilkan, rata-rata berwarna hijau dengan rentang RSL yaitu -39 dBm hingga $-29 \mathrm{dBm}$. Maksimum RSL sebesar $-11 \mathrm{dBm}$ di representasikan dengan warna merah sedangkan minimum RSL yang diterima oleh pengguna yaitu $-57 \mathrm{dBm}$ di representasikan dengan warna biru dimana nilai RSL tersebut 
dikategorikan bagus. Adapun chart diagram yang dihasilkan dari simulasi RSL pada skenario 3 ditunjukan pada gambar 13 .

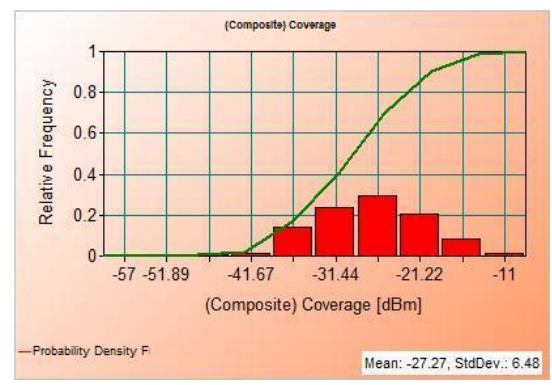

Gambar 13. Chart Diagram SIR Skenario 3 (26 AP)

Grafik hasil penempatan 26 AP skenario 3 ditunjukan pada gambar 13 dimana untuk hasil keseluruhan lantai nilai rata-rata yang dihasilkan sebesar $-27,27 \mathrm{dBm}$, nilai relative frekuensi yang dihasilkan yaitu sebanyak 30\% pengguna mendapatkan nilai RSL sebesar $-30 \mathrm{dBm}$, kemudian nilai minimum RSL yang dihasilkan yaitu sebesar $-57 \mathrm{dBm}$. Kemudian hasil SIR skenario 3 ditunjukan pada gambar 14 dan gambar 15 .

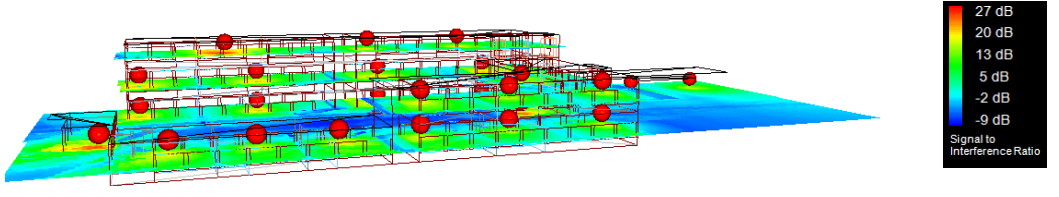

Gambar 14. 3D Plot SIR Skenario 3 (26 AP)

Pada gambar 14 menunjukan hasil SIR yang ditampilkan dengan berbagai macam warna yang menandakan SIR pada area perancangan memiliki nilai yang bervariasi. Berdasarkan informasi dari legend pada gambar 14, nilai maksimum SIR yang didapatkan yaitu sebesar $27 \mathrm{~dB}$ di representasikan dengan warna merah sedangkan minimum SIR sebesar -6 dB di representasikan dengan warna biru pada area perancangan. Adapun grafik yang dihasilkan dari simulasi SIR ditunjukan pada gambar 15.

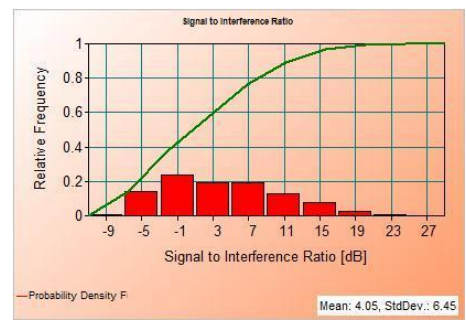

Gambar 15. Chart Diagram SIR Skenario 3 (26 AP)

Dapat dilihat pada gambar 15 nilai rata-rata SIR yang dihasilkan yaitu sebesar 4,05 dB (SIR normal), nilai relative frekuensi yang dihasilkan yaitu sebanyak $22 \%$ pengguna mendapatkan SIR sebesar $-1 \mathrm{~dB}$ yang tergolong dalam kategori buruk. Kemudian hasil minimum SIR didapatkan nilai sebesar -9 dB. 


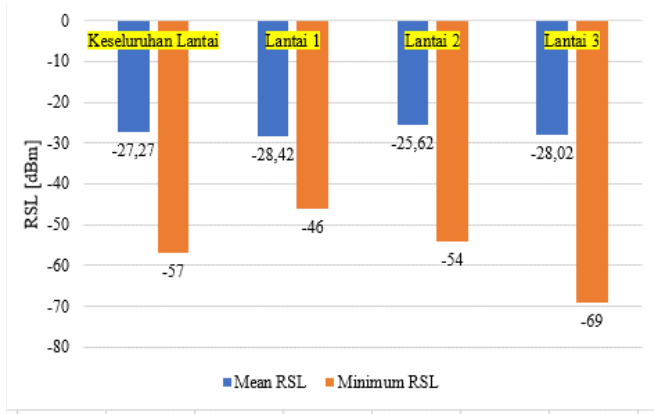

Gambar 16. Diagram Chart RSL Skenario 3 (26 AP)

Kemudian hasil simulasi RSL pada keseluruhan lantai, lantai 1, lantai 2, dan lantai 3 ditunjukan pada gambar 16. Dapat dilihat pada diagram chart tersebut, rata-rata RSL yang diterima oleh pengguna sudah dikategorikan sangat bagus (RSL diatas $-40 \mathrm{dBm}$ ). Nilai minimum RSL yang dihasilkan juga dalam kategori bagus (berada pada rentang $-40 \mathrm{dBm}$ hingga $-50 \mathrm{dBm}$ ). Adapun hasil simulasi SIR ditunjukan pada gambar 17.

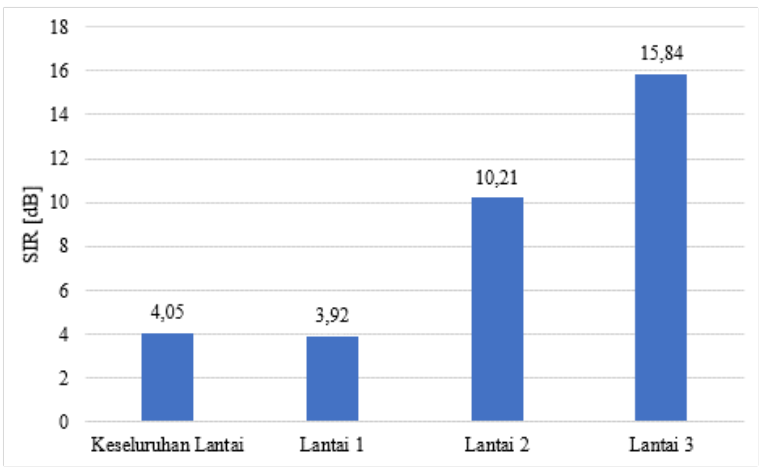

Gambar 17. Diagram Chart RSL Skenario 3 (26 AP)

Hasil SIR yang didapatkan berdasarkan gambar 17 menghasilkan nilai rata-rata SIR pada keseluruhan lantai, lantai 1, lantai 2, dan lantai 3 dalam kategori normal (berada pada rentang $1 \mathrm{~dB}$ hingga $15 \mathrm{~dB}$ ).

A. Perbandingan Existing dengan Optimasi Peremcanaan Ulang

Pada Tabel 6, gambar 18, dan gambar 19 menunjukan hasil perbandingan antara simulasi existing dengan simulasi optimasi perencanaan ulang.

Tabel 6. Perbandingan Existing dengan Optimasi

\begin{tabular}{|c|c|c|c|c|c|c|c|c|}
\hline \multirow[b]{2}{*}{ Keadaan } & \multicolumn{2}{|c|}{ Keseluruhan Lantai } & \multicolumn{2}{|c|}{ Lantai 1} & \multicolumn{2}{|c|}{ Lantai 2} & \multicolumn{2}{|c|}{ Lantai 3} \\
\hline & $\operatorname{RSL}(\mathrm{dBm})$ & $\begin{array}{c}\text { SIR } \\
(\mathrm{dB})\end{array}$ & $\begin{array}{c}\text { RSL } \\
(\mathrm{dBm})\end{array}$ & $\begin{array}{l}\text { SIR } \\
(\mathrm{dB})\end{array}$ & $\begin{array}{c}\text { RSL } \\
(\mathrm{dBm})\end{array}$ & $\begin{array}{l}\text { SIR } \\
(\mathrm{dB})\end{array}$ & $\begin{array}{c}\text { RSL } \\
\text { (dBm) }\end{array}$ & $\begin{array}{r}\text { SIR } \\
(\mathrm{dB})\end{array}$ \\
\hline \multirow[b]{2}{*}{ Existing } & $\begin{array}{l}\text { Mean: } \\
-37,29\end{array}$ & $\begin{array}{c}\text { Mean : } \\
6,57\end{array}$ & $\begin{array}{l}\text { Mean: } \\
-38,11\end{array}$ & $\begin{array}{c}\text { Mean : } \\
8,21\end{array}$ & $\begin{array}{l}\text { Mean: } \\
-38,39\end{array}$ & $\begin{array}{c}\text { Mean: } \\
11,56\end{array}$ & $\begin{array}{l}\text { Mean: } \\
-37,48\end{array}$ & $\begin{array}{l}\text { Mean } \\
25,96\end{array}$ \\
\hline & $\begin{array}{c}\text { Receive } \\
\text { Min: } \\
-64\end{array}$ & $\begin{array}{c}\text { Receive } \\
\text { Min : } \\
-7\end{array}$ & $\begin{array}{c}\text { Receive } \\
\text { Min: } \\
-61\end{array}$ & $\begin{array}{c}\text { Receive } \\
\text { Min : } \\
-6\end{array}$ & $\begin{array}{c}\text { Receive } \\
\text { Min: } \\
-74\end{array}$ & $\begin{array}{c}\text { Receive } \\
\text { Min : } \\
-4\end{array}$ & $\begin{array}{c}\text { Receive } \\
\text { Min: } \\
-79\end{array}$ & $\begin{array}{c}\text { Receive } \\
\text { Min: } \\
0\end{array}$ \\
\hline \multirow[b]{2}{*}{ Optimasi } & $\begin{array}{l}\text { Mean: } \\
-27,27\end{array}$ & $\begin{array}{c}\text { Mean : } \\
4,05\end{array}$ & $\begin{array}{l}\text { Mean: } \\
-28,42\end{array}$ & $\begin{array}{c}\text { Mean : } \\
3,92\end{array}$ & $\begin{array}{l}\text { Mean: } \\
-25,62\end{array}$ & $\begin{array}{c}\text { Mean: } \\
10,21\end{array}$ & $\begin{array}{l}\text { Mean: } \\
-28,02\end{array}$ & $\begin{array}{r}\text { Mean } \\
15,84\end{array}$ \\
\hline & $\begin{array}{l}\text { Receive } \\
\text { Min: } \\
-57\end{array}$ & $\begin{array}{c}\text { Receive } \\
\text { Min: } \\
-9\end{array}$ & $\begin{array}{c}\text { Receive } \\
\text { Min: } \\
-46\end{array}$ & $\begin{array}{l}\text { Receive } \\
\text { Min: } \\
-8\end{array}$ & $\begin{array}{l}\text { Receive } \\
\text { Min: } \\
-54\end{array}$ & $\begin{array}{l}\text { Receive } \\
\text { Min: }\end{array}$ & $\begin{array}{c}\text { Receive } \\
\text { Min: } \\
-69\end{array}$ & $\begin{array}{c}\text { Receiv } \\
\text { Min: } \\
-3\end{array}$ \\
\hline
\end{tabular}

Dari gambar 18 didapatkan hasil RSL optimasi lebih baik daripada hasil RSL existing (dari -37,29 dBm menjadi $-27,27 \mathrm{dBm}$ ). Dan dari keseluruhan lantai, lantai 1, 2, dan 3 nilai RSL optimasi dalam kategori sangat bagus (RSL diatas $-40 \mathrm{dBm}$ ). 


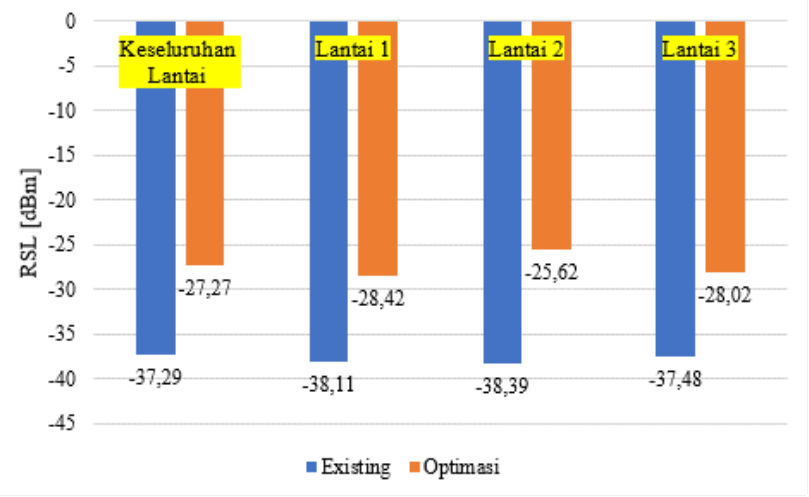

Gambar 18. Perbandingan RSL Existing dengan Optimasi

Dapat dilihat pada gambar 19 menunjukan hasil perbandingan SIR existing dengan optimasi. Pada hasil SIR existing untuk keseluruhan lantai, lantai 1, dan lantai 2 dikategorikan normal (berada pada rentang 1 $\mathrm{dB}$ hingga $15 \mathrm{~dB}$ ) sedangkan pada lantai 3 dikategorikan bagus (berada pada rentang $16 \mathrm{~dB}$ hingga $30 \mathrm{~dB}$ ). Hasil SIR optimasi secara keseluruhan dikategorikan normal.

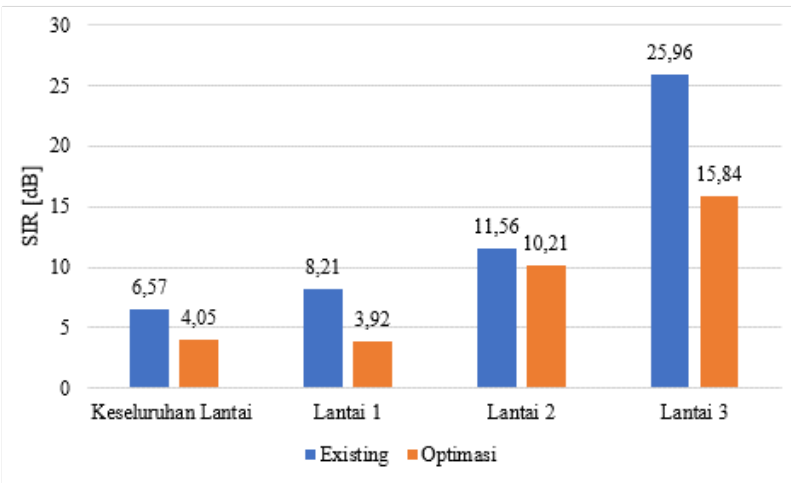

Gambar 19. Perbandingan SIR Existing dengan Optimasi

\section{KESIMPULAN}

Pada peneltian ini dapat disimpulkan hasil RSL pada simulasi AP existing menunjukkan bahwa pada lantai 2 dan lantai 3 masih terdapat pengguna yang mendapatkan kuat sinyal sebesar $-74 \mathrm{dBm}$ dan $-79 \mathrm{dBm}$ yang termasuk kategori buruk. Sedangkan nilai rata-rata SIR pada simulasi AP existing dalam kategori normal. Dari hasil RSL pada lantai 2 dan lantai 3 tersebut maka perlu dilakukan optimasi perencanaan ulang access point. Berdasarkan perhitungan, didapatkan jumlah AP sebanyak 26 AP dari perhitungan cakupan wilayah dengan metode Pathloss COST 231 Multiwall dan 20 AP dari perhitungan kapasitas pengguna dengan metode OBQ. Dari hasil simulasi perencanaan ulang, jumlah AP yang optimal yaitu 26 AP dengan posisi AP ditempatkan ditepi bagian depan dengan RSL yang dihasilkan sebesar -27,27 dBm dan SIR yang dihasilkan sebesar 4,05 dB. Semakin banyak AP maka kuat sinyal yang dihasilkan semakin bagus. RSL yang dihasilkan pada simulasi optimasi dengan jumlah 26 AP lebih baik dibandingkan dengan hasil RSL pada simulasi AP existing dengan jumlah 15 AP (dari -37,29 dBm menjadi -27,27 dBm). Akan tetapi semakin banyak AP mengakibatkan terjadinya interferensi. 


\section{DAFTAR Pustaka}

[1] E. D. Sinaga and M. Pinem, "Analisis Penerapan Model Propagasi Empiris Cost-231 Multi-Wall Pada Gedung walayan yang dimodelkan," Singuda Ensikom, vol. 14, no. -, pp. 95-100, 2016.

[2] S. F. Komalin, U. K. Usman and A. Hambali, "Analisa dan Perencanaan Indoor WIFI IEEE 802.11n Pada Gedung Tokong Nanas," Seminar Nasional Inovasi dan Aplikasi Teknologi Industri (SENATI) 2016, pp. B.356-B.361, 2016.

[3] M. A. Amanaf, E. S. Nugraha, and D. Kurnianto, "Analisis Simulasi Model COST-231 Multiwall Pathloss Indoor Berbasis Wireless Sensor Network pada Aplikasi Absensi Mahasiswa dengan Tag RFID Menggunakan RPS ( Radiowave Propagation Simulator ). Analysis of Wireless Sensor Network-based Indoor COST-231 Multiwall Path Loss Model on Student Attendance Application with RFID Tag using RPS ( Radiowave Propagation Simulator )," vol. 16, no. 1, pp. 17-26, 2018.

[4] H.F. Assidiq, Kupas Tuntas Wi-Fi, Surya University, 2014.

[5] Amin Babiker A. Mustafa, Ashraf A. Osman Ramia Babiker Mohammed Abdelrahman, "A Comparison between IEEE 802.11a, b, g, n and ac Standards," IOSR Journal of Computer Engineering, vol. 17, pp. 1-3, Oktober 2015.

[6] M. Azhar, e-Book WiFi "IEEE 802.11n",Yogyakarta, 2014

[7] P. Titahningsih, R. Primananda and S. R. Akbar, "Perancangan Penempatan Access Point untuk Jaringan WiFi Pada Kereta Api Penumpang," Pengembangan Teknologi Informasi dan Imu Komputer, vol. 2, no. -, pp. 2008-2015, 2017.

[8] Mobile Comm Laboratory, "Femtocell LTE Planning”, Institut Teknologi Telkom, Bandung, 2013.

[9] F. K. Utami, "Perencanaan Femtocell 4G LTE 1800 MHz Studi Kasus Gedung Baru ST3 Telkom Purwokerto," Proceedings Seminar Nasional Teknik Elektro (FORTEL 2016), Vols. -, no. -, pp. 131-135, 2016

[10] T. A. Mahyu, A. Norma, and M. A. Amanaf, "Perancangan dan Analisis Jaringan Indoor Femtocell LTE 2300 MHz di Gedung Java Heritage Hotel Purwokerto dengan Menggunakan Radiowave Propagation Simulator,” in CITEE 2017, 2017, vol. 2, pp. 34-41. 